\title{
Confounding case of seromucinous hamartoma
}

\author{
Neal Rajan Godse, ${ }^{1}$ Giuseppe Vittorio Staltari, ${ }^{1}$ Katherine Doeden, ${ }^{2}$ \\ Grant Shale Gillman (1) ${ }^{1}$
}

${ }^{1}$ Otolaryngology, University of Pittsburgh Medical Center, Pittsburgh, Pennsylvania, USA ${ }^{2}$ Pathology, Pittsburgh Veterans Affairs Medical Center, Pittsburgh, Pennsylvania, USA

\section{Correspondence to} Dr Grant Shale Gillman; gillgs@upmc.edu

Accepted 3 March 2021
A) Check for updates

(c) BMJ Publishing Group Limited 2021. No commercial re-use. See rights and permissions. Published by BMJ.

To cite: Godse NR, Staltari GV, Doeden K, et al. BMJ Case Rep

2021:14:e240460

doi:10.1136/bcr-2020-

240460

\section{SUMMARY}

A 67-year-old man presented with progressive diplopia. On evaluation, he was noted to have bilateral palsies of cranial nerves III, IV and VI as well as a unilateral right true vocal fold paralysis. CT and MRI studies demonstrated a T2-bright left ethmoid mass with no evidence of bony erosion. Direct visualisation demonstrated a polypoid appearing mass of the left sphenoethmoid recess. Operative biopsy was pursued with final pathology demonstrating benign seromucinous hamartoma. Subsequent blood work demonstrated high titres of anti-acetylcholine receptor antibodies consistent with myasthenia gravis. The patient was started on pyridostigmine with improvement in his ocular cranial neuropathies.

\section{BACKGROUND}

We present an interesting diagnostic scenario of a patient with multiple cranial neuropathies and confounding imaging findings of a unilateral nasal mass. The presence of a nasal mass with bulbar palsies, appropriately, created a high concern for an acute infectious process or malignancy. Biopsy of the mass, ultimately, revealed seromucinous hamartoma — a rare, benign pathology. Laboratory evaluation demonstrated high titres of anti-acetylcholine receptor antibodies, leading to a diagnosis of myasthenia gravis. This case serves to highlight a systematic approach to evaluating a unilateral nasal mass and the clinical histopathological features of a rare, sinonasal pathology.

\section{CASE PRESENTATION}

A 67-year-old man developed progressive diplopia over the course of 2 weeks. Medical history was notable for diabetes mellitus; surgical, family and social histories were unremarkable. He was evaluated by ophthalmology and was noted to have bilateral ophthalmoplegia. Extraocular movement testing revealed bilateral complete palsies of cranial nerves III, IV and VI. The patient denied a recent history of nasal congestion, facial pressure, rhinorrhoea, epistaxis, dysosmia, dysphagia, odynophagia, otalgia or lymphadenopathy.

\section{INVESTIGATIONS}

He subsequently underwent CT scans and MRI scans to identify any parenchymal or vascular lesions (figure 1). The scans were notable for a T2-bright lesion involving the left posterior ethmoid air cells and sphenoid sinus. Given this finding, otolaryngology was consulted for direct visualisation and biopsy of the lesion. Nasal endoscopy and flexible fiberoptic laryngoscopy demonstrated a polypoid-appearing mass occupying the left sphenoethmoid recess and a right true vocal fold paralysis (figure 2).

\section{DIFFERENTIAL DIAGNOSIS}

The working differential diagnoses were broadly grouped into three categories: infectious disease,

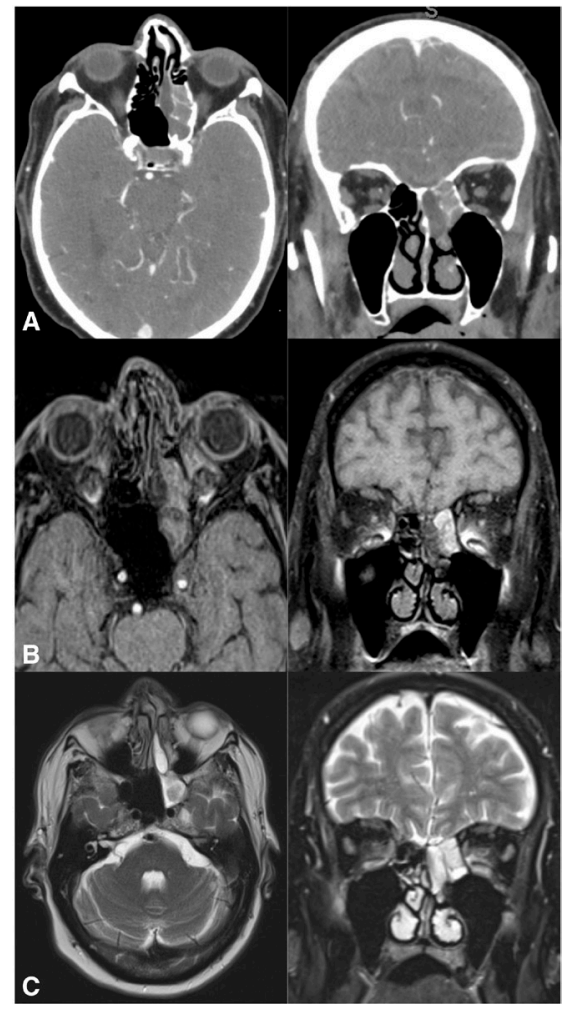

Figure 1 Left-sided lesion involving the posterior ethmoids and the sphenoid sinus. (A) CT scan. (B) T1weighted MRI. (C) T2-weighted MRI.

malignant neoplasia and systemic disease. Invasive fungal sinusitis was the most concerning infectious possibility given multiple cranial neuropathies with concomitant diabetes; however, the endoscopic features of a polypoid mass with normal surrounding mucosa was not consistent with invasive fungal sinusitis. The findings of a space occupying lesion with cranial neuropathies also created a concern for a malignancy. Squamous cell carcinoma and lymphoma were the most concerning possibilities-however, bilateral cranial neuropathies were not consistent with mass effect or invasion from a unilateral lesion. Moreover, there was no evidence of bone erosion or systemic B symptoms. Within the systemic disease category, multiple sclerosis and myasthenia gravis were the most likely diagnoses, but would imply that the sinonasal lesion was coincidental and unrelated. The possibility of the lesion being unrelated was supported by the lack of sinonasal symptoms. Ultimately, biopsy results demonstrated benign, seromucinous hamartoma and laboratory evaluation demonstrated anti-acetylcholine receptor antibodies.

\section{OUTCOME AND FOLLOW-UP}

The workup resulted in finding a benign seromucinous hamartoma that was unrelated to his presenting 


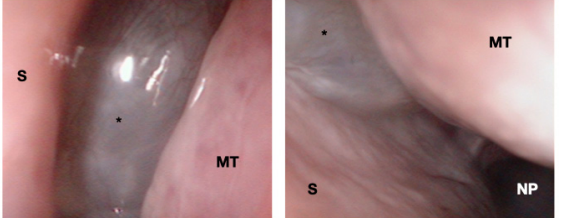

Figure 2 Endoscopic appearance of sinonasal mass. *Denotes mass; MT, middle turbinate; NP, nasopharynx; S, septum.

symptoms, as well as anti-acetylcholine receptor antibodies consistent with myasthenia gravis. The patient was followed for over a year after diagnosis. He noted that he would occasionally still develop diplopia and blurry vision, especially if he forgot to take a dose of pyridostigmine. He denied any nasal obstruction, drainage, facial pain or dysosmia. The patient is still living.

\section{DISCUSSION}

Hamartomas of the nasal cavity are rare and are typically divided into three subcategories: chondromesenchymal hamartoma, respiratory epithelial adenomatoid hamartoma and seromucinous hamartoma. ${ }^{1}$ Fewer than 40 cases of seromucinous hamartoma have been reported in the literature. ${ }^{2}$ The lesions are typically described as arising posteriorly in the nasal cavity though they have been found arising from the septum, ${ }^{3}$ middle turbinate ${ }^{2}$ and uncinate process. ${ }^{2}$ They are often asymptomatic, incidental findings; however, when symptomatic they are usually associated with nasal congestion, rhinorrhoea and epistaxis. Grossly, the lesions are polypoid in appearance and may be broadly based or arise from a stalk. ${ }^{4}$

Histologically, seromucinous hamartoma are characterised by respiratory epithelia overlying the surface of the lesion with disorganised, lobular proliferation of seromucinous tubules in a variable stroma ranging from oedematous to hyalinised (figure 3). These tubules are lined by bland cuboidal epithelium. By immunohistochemistry, the seromucinous glands stain with cytokeratin 7, S100, SOX10 and cytokeratin 19, but are negative for cytokeratin 20. Seromucinous glands lack surrounding basal cell layers as demonstrated by negative p63 and high molecular weight cytokeratin staining.
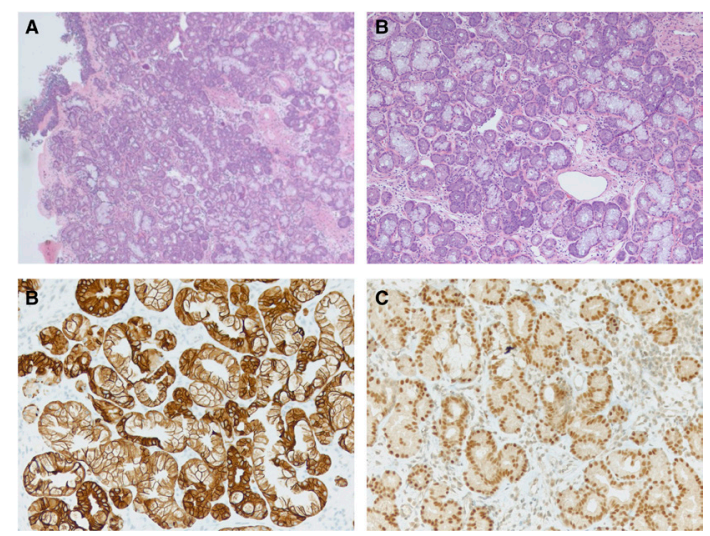

Figure 3 Histological appearance of sinonasal hamartoma. (A) Lobules of bland seromucinous glands (20x). (B) Lobules contain a mix of serous and mucinous epithelial cells (100x). (C) Cytokeratin 7 positive in both serous and mucinous epithelial cells (200x). (D) SOX10 is diffusely positive in the glandular cells (200x).
Patient's perspective

It was scary to have blurry vision-when I first got to the hospital I thought I was going to be blind. Then (the doctors) told me there was something growing in my nose-I thought I had cancer and that I may die. They did the surgery on my nose, which wasn't that bad, and told me it wasn't cancer. I started taking the [pyridostigmine] which has helped. My eyes still don't move very well and I see double sometimes. But the medication helps-if I don't take it things get worse.

\section{Learning points}

- Seromucinous hamartoma is a rare benign lesion that often presents as posteriorly-based sinonasal mass.

- Seromucinous hamartomas are often asymptomatic; when symptomatic they are associated with congestion and rhinorrhoea - the presence of cranial neuropathies should prompt an investigation into other diagnoses.

- The workup of a unilateral nasal mass should proceed in a systematic way and take into account symptoms, physical examination findings, location, imaging characteristics and appearance on direct visualisation; a broad differential diagnosis is critical.

The differential diagnosis for a unilateral nasal mass is large, but can broadly be divided into malignant and benign lesions. Pertinent malignant lesions include squamous cell carcinoma, adenocarcinoma, salivary gland carcinomas, lymphoma, neurovascular malignancies and mesenchymal malignancies. These lesions would likely present with worsening sinonasal symptoms (eg, congestion, bleeding, pain), cranial neuropathies and other malignant symptoms (eg, weight loss, neck mass). Pertinent benign lesions include inverted papilloma, antrochoanal polyp, juvenile nasopharyngeal angiofibroma and sinonasal hamartoma. Benign lesions may present with similar sinonasal symptoms but are unlikely to create cranial neuropathies (unless due to compressive effect) or manifest with systemic symptoms.

Contributors GSG, NRG and GVS designed the report. NRG, GVS and KD collected clinical information. NRG discussed the study with the patient, obtained consent and recorded the patient's perspective. NRG wrote the first draft of the manuscript, assembled the figures and performed the literature review. NRG, GVS, KD and GSG reviewed and edited the manuscript and figures.

Funding The authors have not declared a specific grant for this research from any funding agency in the public, commercial or not-for-profit sectors.

Competing interests None declared.

Patient consent for publication Obtained.

Provenance and peer review Not commissioned; externally peer reviewed.

ORCID iD

Grant Shale Gillman http://orcid.org/0000-0001-8068-9220

\section{REFERENCES}

1 Khan RA, Chernock RD, Lewis JS. Seromucinous hamartoma of the nasal cavity: a report of two cases and review of the literature. Head Neck Pathol 2011;5:241-7.

2 Huang Y-W, Kuo Y-J, Ho C-Y, et al. Sinonasal seromucinous hamartoma. Eur Arch Otorhinolaryngol 2018;275:743-9.

3 Weinreb I. Low grade glandular lesions of the sinonasal tract: a focused review. Head Neck Pathol 2010;4:77-83.

4 Tong KN, Serra RM, Shih RY, et al. Seromucinous hamartoma of the nasal cavity. Head Neck Pathol 2019;13:239-42. 
Copyright 2021 BMJ Publishing Group. All rights reserved. For permission to reuse any of this content visit https://www.bmj.com/company/products-services/rights-and-licensing/permissions/

BMJ Case Report Fellows may re-use this article for personal use and teaching without any further permission.

Become a Fellow of BMJ Case Reports today and you can:

- Submit as many cases as you like

Enjoy fast sympathetic peer review and rapid publication of accepted articles

Access all the published articles

Re-use any of the published material for personal use and teaching without further permission

Customer Service

If you have any further queries about your subscription, please contact our customer services team on +44 (0) 2071111105 or via email at support@bmj.com.

Visit casereports.bmj.com for more articles like this and to become a Fellow 